\title{
ARTICLES
}

\section{REGULATORY SANDBOXES (EXPERIMENTAL LEGAL REGIMES) FOR DIGITAL INNOVATIONS IN BRICS}

\author{
ELIZAVETA GROMOVA, \\ South Ural State University (Chelyabinsk, Russia) \\ TJAŠA IVANC, \\ University of Maribor (Maribor, Slovenia)
}

https://doi.org/10.21684/2412-2343-2020-7-2-10-36

Step by step, new digital technologies are capturing different spheres of our life. The opportunities of their application are almost infinite, and potential is very promising. But digital innovations as a trend represent a challenge for every modern state. Especially for member-countries of the BRICS union who seek to become the world's leading countries. For this reason, the most important task for the members of BRICS is to create adequate "smart" regulation, which offers alternative ways of regulatory impact on transforming business relations. Using the regulatory sandbox as an experimental legal regime is one of the ways to test the creation, production, and realization of digital innovation. Having been first applied in 2016 in the United Kingdom, nowadays this model is successfully implemented in such countries as Singapore, Australia, and the United Arab Emirates. Member-countries of BRICS are only beginning to adopt this unorthodox tool; in most of its countries the legal framework is ongoing now. The aim of this research is to analyze current legislation and legal framework on the regulatory sandboxes in BRICS countries, define features of national models, difficulties and further prospects of its usage. This research is based on the comparative and formal juridical analysis of legislation, draft laws, and research papers dedicated to regulatory sandboxes in BRICS. The authors identify different barriers and risks of using regulatory sandboxes for the digital innovations successfully and offer some ways to overcome these challenges, including the formulation of guidelines for operating regulatory sandboxes based on a balance of public and private interests. The authors conclude that it is necessary to 
update legislation on the regulatory sandboxes for reaching positive effect from the digital transformation and make several suggestions for optimization its provisions. The results achieved in research paper can be used both in the lawmaking process as well as the foundation for further scientific researches.

Keywords: regulatory sandboxes; experimental legal regime; smart regulation; digital economy; innovations.

Recommended citation: Elizaveta Gromova \& Tjaša Ivanc, Regulatory Sandboxes (Experimental Legal Regimes) for Digital Innovations in BRICS, 7(2) BRICS Law Journal 10-36 (2020).

\section{Table of Contents}

\section{Introduction}

1. Regulatory Sandboxes as a New Tool of Smart Regulation and Innovations' Facilitator: Definition, Genesis, and Related Constructions

2. Status of the Legislation on the Regulatory Sandboxes in MemberCountries of BRICS

2.1. Regulatory Sandboxes in the Federative Republic of Brazil: Readiness for Legal Framework Process

2.2. Experimental Legal Regimes (Regulatory Sandboxes) for the Digital Innovations in the Russian Federation: Problems of the Draft Law

2.3. Regulatory Sandboxes in the Republic of India: The Beginning of the Legal Framework's Creation

2.4. Regulatory Sandboxes in the People's Republic of China: Aspiration to Get Ahead

2.5. The Republic of South Africa: Looking for Proof of Regulatory Sandboxes' Legitimacy and Efficiency

3. Global World Trends in Regulatory Sandboxing: The Way to Global Regulatory Sandbox or "Sandbox for Sandboxes"

4. Recommendations on Setting Up a Regulatory Sandbox for BRICS Countries: Keeping a Balance Between Private and Public Interests Conclusion

\section{Introduction}

The fourth industrial revolution and global digitization process have led to the appearance of new, innovative, or "disruptive" technologies, which affect and transform different spheres of modern social life. Such innovations as high-performance and cloud 
computing, distributed ledger technologies, neurotechnology, artificial intelligence, quantum technologies, the industrial Internet of Things, components of robotics and sensorics, wireless technologies, and virtual and augmented reality technologies have already changed existing reality and further development of the society.

Today, the famous quotation by N. Rothschild"the one who owns the informationowns the world" could be paraphrased better as "the one who owns digital technologies - owns the world." This quotation became a motto for the countries seeking to take become the world's economic and political leader in the global landscape. That is why one of the most important goals of modern states is to create and apply competitive innovation technologies. This ambitious goal was set by the Federative Republic of Brazil, the Russian Federation, the Republic of India, the People's Republic of China, and the Republic of South Africa - a group of five fastest-growing emerging markets.' The members of the BRICS union are well-known all over the world as the fastest-growing major countries. ${ }^{2}$ According to experts, the total volume of economies of the BRICS countries will exceed the volume of economies of the G-7 countries by $2050 .^{3}$

For further intensive development of member-countries of the BRICS union and to enhance their potential to hold a leading position among the other countries in the world, the member-countries should stimulate creation of the digital technologies within their borders.

The emergence of digital technologies has been greeted by almost infinite possibilities of its application and huge potential. But the rapidly-evolving technological landscape provides challenges for policymakers, business entities, and academic society. ${ }^{4}$ They seek to find the answers to such questions as how to regulate business activity with these innovations, how to attract companies to create digital technologies, and how to use these technologies with more benefits and while minimizing risks of failure or harm.

The point is that under the conditions of constant regulation, the digital innovation market is becoming a real "minefield" for innovators and business entities. Market participants are at risk of sanctions any of the norms that were developed before digital innovations appeared. ${ }^{5}$

Adriana Brigante Deorsola et al., Intellectual Property and Trademark Legal Framework in BRICS Countries: A Comparative Study, 49 World Patent Information 1 (2017).

2 See Mizuho Research Institute, Comparative Analysis of the BRICS (abstract) (March 2006) (Apr. 10, 2020), available at http://www.esri.go.jp/jp/prj/hou/hou016/hou16a-2-1.pdf.

3 Коротков С.А., Кульков И.В. Развитие БРИКС // Вестник «ЮНИДО в России». 2013. № 11. С. 54 [Sergei А. Korotkov \& Igor V. Kulkov, Development of BRICS, 11 Bulletin of UNIDO 54 (2013)].

4 Lev Bromberg et al., Fintech Sandboxes: Achieving a Balance Between Regulation and Innovation, 28(4) Journal of Banking and Finance Law and Practice 314 (2017).

5 Chamber of Digital Commerce, Global Regulatory Sandbox Review: An Overview on the Impact, Challenges, and Benefits of Regulatory FinTech Sandboxes, 21 November 2017 (Apr. 10, 2020), available at https:// digitalchamber.org/wp-content/uploads/2017/11/Regulatory-Sandbox-Review_Nov-21-2017_2.pdf. 
That is why, there is no doubt, that policymakers must create favorable conditions to apply these technologies safely and beneficial to regulators, innovators, businesses and consumers. For this reason, the chosen approach to the regulation of digital technologies is crucial in this case.

It is therefore necessary to search for the new instruments of regulation of the digital technologies which could respond both to public and private interests.

One of such tools is a regulatory sandbox. Its' application aimed at encouraging innovation activities by allowing business entities to test their offerings in a "safe" environment, provide an example of a shift away from traditional regulatory approaches and represent an attempt to embrace principles of proactive, dynamic and responsive regulation.

Launched on 2016 in United Kingdom, nowadays this model is successfully applying in such countries as Singapore, Australia, UAE, USA, and in member-countries of the European Union, etc.

The BRICS countries are only in the first steps of using this unorthodox tool, in most of the mentioned countries the legal framework on the regulatory sandboxes is ongoing or just beginning now. That is why creating an adequate legal base of regulation for the regulatory sandboxes in the digital era by the members of the BRICS countries plays a significant role in the further development of the Federative Republic of Brazil, the Russian Federation, the People's Republic of China, the Republic of India, and the Republic of South Africa.

It should be noted that there are many research papers and overviews dedicated to analysis of regulatory sandboxes. ${ }^{6}$ These reviews vary considerably in objectives, scope, and focus and provide useful insight into the interaction between governmental authorities, companies, consumers, and counterparties. Some of mentioned research papers considered peculiarities of application of the regulatory sandboxes' regime in international unions or some foreign countries; ${ }^{7}$ or were dedicated to the legislation or legal framework on one or two members of the BRICS group; ${ }^{8}$ or, most commonly, investigated the role of the regulatory sandboxes in separate spheres such as FinTech. ${ }^{9}$ However, we were unable to find research

6 Ivo Jenik \& Kate Lauer, Regulatory Sandboxes and Financial Inclusion, CGAP Working Paper (October 2017) (Apr. 10, 2020), available at https://www.cgap.org/sites/default/files/Working-Paper-RegulatorySandboxes-Oct-2017.pdf.

7 Péter Fáykiss et al., Regulatory Tools to Encourage FinTech Innovations: The Innovation Hub and Regulatory Sandbox in International Practice, 17(2) Financial and Economic Review 68, 69 (2018).

8 See Hendrik C. Marais \& Magdal Pienaar, Evolution of the South African Science, Technology and Innovation System 1994-2010: An Exploration, 2(3) African Journal of Science, Technology, Innovation and Development 82 (2010).

9 See Serdar Kurt \& Ünzüle Kurt, Innovation and Labor Productivity in BRICS Countries: Panel Causality and Co-integration, 195 Procedia - Social and Behavioral Sciences 1295 (2015); Dirk A. Zetzsche et al., Regulating a Revolution: From Regulatory Sandboxes to Smart Regulation, 23(1) Journal of Corporate \& Financial Law 31 (2017). 
papers devoted to analysis of the legal framework and legislation on the regulatory sandboxes of the BRICS members.

The aim of this research is to analyze current legislation and legal framework on the regulatory sandboxes in BRICS countries, define features of national models, difficulties and further prospects of its usage. The paper is based on the application of comparative and formal juridical analysis of the current legislation, legal framework and research papers dedicated to the legislation of BRICS on regulatory sandboxes for creating digital innovations. In particular, the norms of current legislation on regulatory sandboxes and legal framework in the Federative Republic of Brazil, the Russian Federation, the Republic of India, the People's Republic of China, and the Republic of South Africa were analyzed.

\section{Regulatory Sandboxes as a New Tool of Smart Regulation and Innovations' Facilitator: Definition, Genesis, and Related Constructions}

Unprecedented global transformation has made regulators seek balance between the traditional regulatory objectives of economic stability and consumer protection with the objectives of promoting growth and innovations. The emergence of digital innovations generates new opportunities as well as new risks. This fact influences governmental efforts to develop regulation suited to the conditions of the new digital reality. According to researchers, regulators must develop new approaches to the regulation of digital technologies. ${ }^{10}$

Modern concepts of regulation and governance, such as "smart regulation,"'"good governance," and "agile governance" suggest that regulations and governmental management must be flexible, "sensitive" to the process of transformation of existing relations, and based on the application of new or unorthodox regulatory methods and models. These concepts are based in the fact that both modern governance and legal regulation must adapt to the rapidly changing world, seeking tools of smart regulation which supports innovation.

The spread of the digital technologies led to the emergence of new ways and means of regulation. Analysis of international and foreign experience in regulation of digital technologies allows us to define several general approaches to its regulation.

The first can be called the "do nothing" or "wait and see" approach. Its roots are based on the $18^{\text {th }}$ century economic theory "laissez-faire" (from French - "do not interfere"), that opposed any government intervention into business affairs." This form of regulation involves the application of the existing restrictive or permissive

10 See Zetzsche et al. 2017, at 32; Fáykiss et al. 2018, at 68.

11 See Mario Tonveronachi, Financial Innovation and System Design, 63(253) PSL Quarterly Review 131, 132 (2010). 
approach, depending on the context. Currently, the "do nothing" approach is applied by regulators when an innovation is not yet fully understood, and the regulators choose to let it develop before deciding whether (and how) to intervene. It is noteworthy to mention, that China's policymakers applied this approach for a long period for innovations by FinTech. ${ }^{12}$

But according to modern experts, applying this approach "is a terribly difficult task for regulators and supervisors nowadays."13 The need to strike a balance between the freedom to innovate and the risks and dangers coming from unregulated usage has led governments to seek new approaches to regulation.

The next approach is "cautious permissiveness through flexibility and forbearance," involving softening or relaxation of existing rules in specific contexts. This approach is widespread all over the world and is applied when encouraging the development of innovations. For example, residents conducting innovative activity in the boundaries of innovation special economic zones or innovational parks are free from paying certain taxes and custom duties. However, this approach is not free from shortcomings. There can be situations when the companies benefitting from this approach do not produce competitive innovation or their activity is inefficient for the state and society.

Another approach is aimed at the establishment of new tools of regulation of technological innovations. When seeking new regulation tools, modern states consider such tools as deregulation, co-regulation, risk-based regulation, or compliance-based regulation tools. However, the application of new regulation might not be useful as itself. That is why we need to seek better regulation for digital innovations, rather than completely new regulations. According to experts, better regulation does not involve favoring certain policies or objectives over others, but ensuring that the policy solution is the best and least burdensome way to reach those objectives and being honest about how well solutions are working. ${ }^{14}$

Considering the shortcomings of the above-mentioned ways of regulation, some jurisdictions have concluded that it is both premature to bring in new regulation and risky just to "wait and see."They have chosen to provide regulatory guidance of how new technologies fit into existing legal frameworks and provide sandboxing opportunities for new models. ${ }^{15}$

12 Jenik \& Lauer, supra note 6.

13 Id.

14 Communication from the Commission to the European Parliament, the Council, the European Economic and Social Committee and the Committee of the Regions "Better Regulation for Better Results" - An EU Agenda (Apr. 10, 2020), available at https://eur-lex.europa.eu/legal-content/EN/ TXT/?uri=CELEX\%3A52015DC0215.

15 OECD Directorate for Financial and Enterprise Affairs Corporate Governance Committee, Blockchain Technology and Corporate Governance:Technology, Markets, Regulation and Corporate Governance, DAF/ CA/CG/RD(2018)1/REV1, 6 June 2018 (Apr. 10, 2020), available at https://www.oecd.org/officialdocuments/ publicdisplaydocumentpdf/?cote=DAF/CA/CG/RD(2018)1/REV1\&docLanguage=En. 
The next approach is "test-and-learn": regulators, in close cooperation with an innovator, craft a framework to test a new idea in a live environment and adopt safeguards (pursuant to, for example, a memorandum of understanding, no enforcement action letter, or letter of no objection) to minimize the impact of potential failure and to set criteria against which they measure success. Based on testing, regulators decide whether to grant the innovator permission to launch the innovation market-wide, which may involve a licensing process and may require regulatory changes. ${ }^{16}$

The result has been a change to existing frameworks such as the establishment of an experimental legal regime or testing environment to check whether or not the digital technology will operate as intended.

The term "regulatory sandbox" originates from the technology sector, where a "sandbox" is a closed virtual environment designed for testing safely isolated web products or software projects. Another version of the genesis of term "regulatory sandbox" is connected with the pharmaceutical sector where clinical trials are required to prevent consumer harm while testing new innovational medicine or medical technology. ${ }^{17}$

The purpose of the sandbox is to adapt compliance with strict financial regulations to the growth and pace of the most innovative companies in a way that doesn't smother the FinTech sector with rules but also doesn't diminish consumer protection.

The world's first regulatory sandbox was launched in the United Kingdom. Financial Conduct Authority (FCA) set up "Project Innovate" in 2014. The Project envisaged a regulatory sandbox model in which FinTech companies could test innovative products, services, and business models in a live market environment while ensuring that appropriate safeguards are in place through temporary authorization. ${ }^{18}$ FinTech startups or banks could participate in this sandbox. Statistics show that the regulatory sandbox has helped more than 500 companies to develop their innovation activity, with more than 40 firms receiving regulatory authorization. "Project Innovate" has helped the Financial Conduct Authority's reputation for supporting initiatives which boost competition within financial services, which was part of the regulator's postfinancial crisis agenda. The success of the initiative in fostering a fertile FinTech environment is reflected by the growing number of UK-based challenger banks expanding their client bases across the European Union.

Following the success of the United Kingdom's Financial Conduct Authority project on regulatory sandboxes, regulators around the world adopted a similar strategy for FinTech innovation and the UK's concept of the regulatory sandbox became global.

16 Jenik \& Lauer, supra note 6.

17 Ariel Dora Stern, Innovation Under Regulatory Uncertainty: Evidence from Medical Technology, 145 Journal of Public Economics 181, 183 (2018).

18 See Douglas W. Arner et al., The Evolution of Fintech: A New Post-Crisis Paradigm?, 47(4) Georgetown Journal of International Law 1271 (2016). 
Currently, an experimental legal regime of the regulatory sandboxes has been applied in many countries such as Singapore, UAE, Thailand, Australia, USA, France, Hungary, Ireland, Iceland, Italy, Lithuania, Netherlands, Norway, Poland, and more.

Many positive results from regulatory sandboxes have been noted. Firstly, regulatory sandboxes enable companies to experiment (test) their innovations or protocols in a safe environment. This minimizes regulatory risks of infractions. Secondly, regulators learn how new technologies work in a low-risk environment and can adapt examination procedures and regulations as needed. And thirdly, the use of this tool can minimize harm to consumers by providing customer safeguards and consumer protection - by using informed consent, for example.

Figures show that the implementation of a regulatory sandbox in the sphere of FinTech innovations has resulted in an increase of investments from US \$1.8 B to \$19 B in the last five years. Market capitalization of all cryptocurrencies has increased $1.578 \%$ in the past 12 months from US $\$ 14 \mathrm{~B}$ to $\$ 237 \mathrm{~B} .^{19}$

Currently, the mechanism of regulatory sandboxes is used in the sphere of the digital economy as a testing grounds for new business models that are not protected by current regulation, or supervised by regulatory institutions. The afore-mentioned testing grounds are especially relevant in the FinTech world, where there is a growing need to develop regulatory frameworks for emerging innovative business models. For this reason, regulatory sandboxes are also called one of the innovation facilitators. ${ }^{20}$ Apart from the experimental legal regime of a regulatory sandbox, the innovation's ecosystem includes several important initiatives designed to impact innovation, knowledge, and growth.

For example, innovation hubs. Innovation hub generally refers to a regulatorprovided knowledge center open to regulated and unregulated entities. It represents a platform provided by the regulatory authority, where innovators can receive guidance from the authority. Within this framework, the experts of the regulatory authority answer questions from the representatives of innovations and provide assistance in interpreting legal requirements. They also survey the needs for changes to legislation and forward these to the decisionmakers (thereby likely also making the general regulatory environment more favorable for innovations). This institution is available for both unregulated and currently regulated activities; furthermore, both the innovations of newly established enterprises and the new technological solutions of incumbents (e.g. banks, insurers) could be covered by it..$^{21}$ Innovators may receive guidance, advice, and assistance from hub staff, third party experts, or

19 Global Regulatory Sandbox Review, supra note 5.

20 European Securities and Markets Authority (ESMA), European Banking Authority (EBA), European Insurance and Occupational Pensions Authority (EIOPA), Report - FinTech: Regulatory Sandboxes and Innovation Hubs, JC 201874 (Apr. 10, 2020), available at https://www.esma.europa.eu/sites/default/ files/library/jc_2018_74_joint_report_on_regulatory_sandboxes_and_innovation_hubs.pdf.

21 Fáykiss et al. 2018, at 70. 
other experienced parties regarding matters such as legal and policy issues, licensing issues and navigating a complex legal and regulatory system. The Innovation hub can also serve as an opportunity for regulators to learn more about the industry through direct interaction. Global innovation hubs foster collaborative opportunities on an international level. Innovation hubs have been established by competent authorities in Austria, Belgium, Bulgaria, Cyprus, Germany, Denmark, Estonia, Spain, Finland, France, Hungary, Ireland, Iceland, Italy, Liechtenstein, Lithuania, Luxembourg, Latvia, Netherlands, Norway, Poland, Portugal, Romania, and the United Kingdom.

The two innovation facilitators do have some differences. Innovation hubs provide a dedicated point of contact for firms to raise inquiries with competent authorities on FinTech-related issues and to seek non-binding guidance on regulatory and supervisory expectations, including licensing requirements. Regulatory sandboxes, on the other hand, are an experimental legal regime for firms to test innovative financial products, services, or business models pursuant to a specific testing plan agreed by the competent authority.

Beyond regulatory sandboxes, private, proprietary, and industry sandboxes have also been utilized in various fields. Private and proprietary sandboxes also exist for testing and experimentation and are available on a commercial or non-commercial basis. They may offer a development environment, tools, shared data, APIs, sandboxas-a-service, and collaborative platforms. Industry sandboxes are led and operated by industry stakeholders, not regulators. Unlike regulatory sandboxes, an industry sandbox is developed, operated, and owned by industry. It supports the "off-market" testing of solutions, regardless of whether these solutions need to be regulated. It would not give access to any form of regulatory relief..$^{22}$

\section{Status of the Legislation on the Regulatory Sandboxes in Member-Countries of BRICS}

Analysis of the status of the legislation on the regulatory sandboxes in the Federative Republic of Brazil, the Russian Federation, the Republic of India, the People's Republic of China, and the Republic of South Africa shows that it is currently in the development stage (Table 1). Regulatory sandbox regimes have been applied in China (4 regulatory sandboxes) and Russia, which means that the legislation already exists. There is a regulatory sandbox in the sphere of FinTech in the Russian Federation, which is regulated, primarily, by the Action Plan ("Road Map") for the implementation of the "Main Directions for the Development of Financial Technologies for the Period 2018-2020." Meanwhile, the Draft Federal Law "On Experimental Legal Regimes of Digital Innovations" has been prepared.

22 Industry Sandbox, A Development in Open Innovation: Industry Sandbox Consultation Report (May 2017) (Apr. 10, 2020), available at http://industrysandbox.org/wp-content/uploads/2017/05/IndustrySandbox-Consultation-Report-Full.pdf. 
The Reserve Bank of India has already developed Draft Enabling Framework for Regulatory Sandbox in April 2018.

Brazil and South Africa have neither legislation on the regulatory sandbox nor draft laws on this issue. And, where in Brazil the need for the formulation of a draft law has been proved by competent authorities, the situation in South Africa is quite opposite.

Table 1: The Legislation on the Regulatory Sandbox in BRICS

\begin{tabular}{|c|c|c|c|c|c|}
\hline Country & $\begin{array}{l}\text { Federal } \\
\text { Republic } \\
\text { of Brazil }\end{array}$ & Russian Federation & $\begin{array}{l}\text { Republic } \\
\text { of India }\end{array}$ & $\begin{array}{l}\text { People's } \\
\text { Republic } \\
\text { of China }\end{array}$ & $\begin{array}{c}\text { Republic } \\
\text { of South } \\
\text { Africa }\end{array}$ \\
\hline $\begin{array}{c}\text { Current } \\
\text { legislation / } \\
\text { Draft Laws } \\
\text { on the } \\
\text { Regulatory } \\
\text { Sandbox }\end{array}$ & - & $\begin{array}{c}\text { Action Plan ("Road Map") } \\
\text { for the implementation of } \\
\text { the "Main Directions for the } \\
\text { Development of Financial } \\
\text { Technologies for the } \\
\text { Period 2018-2020" (2018) / } \\
\text { Draft Federal Law "On } \\
\text { Experimental Legal Regimes } \\
\text { of Digital Innovations" } \\
\text { (July 2019) }\end{array}$ & $\begin{array}{c}\text { Draft } \\
\text { Enabling } \\
\text { Framework } \\
\text { for } \\
\text { Regulatory } \\
\text { Sandbox } \\
\text { (April 2018) }\end{array}$ & $\begin{array}{l}\text { Guidelines } \\
\text { on the } \\
\text { Regulatory } \\
\text { Sandboxes }\end{array}$ & - \\
\hline
\end{tabular}

\subsection{Regulatory Sandboxes in the Federative Republic of Brazil: Readiness for Legal Framework Process}

According to current research, increased use of digital technologies could impact the productivity of the world's top ten economies, adding US $\$ 1.36$ trillion to those countries' GDP by 2020. In the case of the Republic of Brazil, the impact on GDP could reach US $\$ 97$ billion over the same period, ${ }_{1}^{23}$ leading Brazilian authorities to strive to enhance innovation development of the country.

Until recently, there was no legal framework in adopting a regulatory sandbox regime in the country. But in June 2019, authorities of the Federative Republic of Brazil announced the development of a regulatory sandbox focused on testing business activity with new digital technologies, including blockchain.

The Ministry of Finance, the Central Bank of Brazil, the Securities Commission, and the Superintendent of Private Insurance intents to adapt new regulations to manage FinTech and cryptocurrency advances. According to announcement, the new regulations will affect Brazil's securities, financial, and capital markets.

According to analytics, the goal of this step is to implement regulation in corresponding sectors to ensure compliance with the rules of each segment, regardless of

23 The World Bank: Overview of the Republic of Brazil (Apr. 10, 2020), available at http://www.worldbank. org/en/country/brazil/overview. 
how services and products are delivered, especially in areas of legal certainty, customer and investor protection, and the safety, health, and efficiency of markets. ${ }^{24}$

Despite the United Kingdom's model of the regulatory sandbox, which develops only financial innovation (FinTech) for banking sphere, legal regime of the regulatory sandbox in the Federative Republic of Brazil will be set for cryptocurrencies, artificial intelligence, blockchain, and other digital innovations through more than one regulated market.

In accordance with policy maker opinion, the implementation of this regulatory regime will promote the development of products and services that are more inclusive and of higher quality and can foster constant innovation in the financial, security, and capital markets. ${ }^{25}$ The Government of Brazil hopes to encourage the implementation of blockchain and other advanced technologies in all local public administration unit, which will see the federal and state government divisions implementing evolving technologies like blockchain and artificial intelligence to enhance services to the public.

\subsection{Experimental Legal Regimes (Regulatory Sandboxes) for the Digital Innovations in the Russian Federation: Problems of the Draft Law}

Russia aspires to become one of the world's leading countries by producing digital technologies and implementing them to the different spheres of social life. For this reason, the Russian Federation is keeping track of the global trends in the regulation of the creation and production of digital technologies.

The development of regulatory sandboxes in the Russian Federation occurred in two stages. As BRICS countries and other countries adopted regulatory sandboxes, the first stage of implementing regulatory sandboxes in Russia began more than a year ago as part of the development of the FinTech sphere.

The Bank of Russia has approved "Main Directions for the Development of Financial Technologies for the Period 2018-2020."26 The goals of the development of Financial Technologies'sphere are to promote competition in the financial market; increase the availability, quality, and range of financial services; reduce risks and costs in the financial sector; and increase the level of competitiveness of Russian technologies. These tasks will be carried out in accordance with the Action Plan ("Road Map") for the implementation of the "Main Directions for the Development of Financial Technologies for the Period 2018-2020."

24 PwC, ABFintech, Brazil Fintech Deep Dive 2018 (2018) (Apr. 10, 2020), available at https://www.pwc. com.br/pt/setores-de-atividade/financeiro/2018/fintech_deep_dive_ingles_18.pdf.

25 Brazil Authorities to Develop Regulatory Sandbox for Blockchain, DLT, TokenPost, 17 January 2019 (Apr. 10, 2020), available at https://www.tokenpost.com/Brazil-authorities-to-develop-regulatory-sandboxfor-blockchain-DLT-2245.

26 Bank of Russia, The Main Directions of Development of the Financial Technologies for the Period 20182020 (Apr. 10, 2020), available at https://www.cbr.ru/StaticHtml/File/36231/ON_FinTex_2017.pdf. 
According to the Action Plan ("Road Map") for the implementation of the "Main Directions for the Development of Financial Technologies for the Period 2018-2020," the Bank of Russia would establish a regulatory platform (regulatory sandbox) for the mainstreaming of the mechanisms of piloting innovative financial technologies, products, and services.

Piloting of the innovative financial technologies and services projects on the regulatory platform (sandbox) of the Bank of Russia will be carried out in two forms "testing" and "limited regulatory experiment." At the first stage, piloting will be implemented in the form of "testing," which involves modeling the target process of applying innovative financial technology or service in a test environment, removing risks for consumers. At the second stage, piloting is planned in the form of a "limited regulatory experiment", which involves the implementation of the proposed innovative financial technology or service in real conditions in a limited scope under the control of the Bank of Russia, including within government agencies.

In April 2018, the Bank of Russia initiated the use of a regulatory sandbox for testing innovative financial services and technologies which required changes to the existing regulation. The innovative service from Sberbank for remote management of authority over corporate clients' accounts for operations in bank branches was the first legallyenforced regulatory project in the sandbox of the Central Bank of Russia.

According to experts, due to the intensive digitalization of many spheres of Russian society, the state needs to develop an adequate regulatory framework of regulatory sandboxes with the ability to test innovative technologies in transparent regulatory conditions not only in the field of financial technologies, but also in other areas. ${ }^{27}$

The second stage of the development of a regulatory sandbox in Russia began when the Ministry of Economic Development of the Russian Federation developed the Draft Federal Law “On Experimental Legal Regimes for Digital Innovations."There are two versions of this Draft Law. The earliest version was formed in 2018; the latest - in July 2018. Both are quite different and have their own advantages and disadvantages.

The latest version of the Draft Law "On Experimental Legal Regimes for Digital Innovations" defines the procedure for initiating, establishing, implementing, monitoring, and evaluating the effectiveness of experimental legal regimes in the field of digital innovations (Art. 1). This regime is defined by the legislator as a special regulation in the field of the digital innovations which applies for a given period in relation to a given individual. According to the Draft Law, special regulation in the context of a regulatory sandbox differs from the general regulation, including by indicating the non-use of certain regulatory legal acts (or some of its provisions) of the general regulation and establishing mandatory requirements for licensing,

27 Alexey Yefremov, Regulatory Sandboxes and Experimental Legislation as the Main Instruments of Regulation in the Digital Transformation (Apr. 10, 2020), available at https://www.ifap.ru/pr/2019/n190626a.pdf. 
accreditation, certification, mandatory confirmation of compliance, and obtaining access and permissions.

The objectives of the experimental mode are to approbate the digital innovations for their accelerated implementation and improve the general regulations following the results of the experimental legal regime. The tasks of the experimental mode are: 1) maintaining a special regulation that is different from the general regulation, including by indicating the non-use of certain provisions of the general regulation; 2) assessment of the effectiveness and impact of special regulation.

The legal entity in relation to which such a regime can be established may be a legal entity, an individual entrepreneur, a functional executive body, or the functional body of a local administration, whose activities (actions) based on the use of digital innovation, including in legal relations with an indefinite number of persons, are carried out under the experimental legal regime.

It seems that the main advantage of the Draft Federal Law"On Experimental Legal Regimes of Digital Innovations" is its universality, since the scope of this act is not limited to a specific sector (e.g. FinTech). This means that, unlike such countries as Australia, the United Kingdom, or the United Arabic Emirates, the Russian regulatory sandbox model can be used for experimental creation of the digital innovation for different purposes and spheres, not limited by FinTech.

The other advantage of the Draft Law is the principles of the legal regime of the regulatory sandbox (Art. 4), which outline basic vectors of Russian regulatory sandbox's model. The principles of the experimental legal regime are as follows: transparency (openness); equality of applicants; voluntary participation in the regulatory sandbox; limitation of the experimental mode in time, territory, and range of persons; minimization of deviations from general regulation when establishing an experimental regime; compliance of the special regulation with the Constitution of the Russian Federation and the generally recognized principles and norms of international law, international treaties of the Russian Federation, federal constitutional laws; legitimacy of the activity carried out in accordance with the special regulation determined by the program of the experimental regime; and equality of the participants of the experimental regime.

On the other hand, analysis of this Draft Law revealed several shortcomings. The first issue is in the definition of "digital innovation." It should be noted that, in accordance with the Draft Federal Law "On Experimental Legal Regimes of Digital Innovations," "digital innovation" means "new or substantially improved products (goods, results of work, services, intellectual property), introduced into civil turnover, created or used in the specified areas using technologies that are approved by the Government of the Russian Federation.

In several aspects, this definition runs counter to the basic legal act which regulates scientific, technical, and innovative activities - the Federal Law of 23 August 1996 No. 127-FZ "On Science and the State Scientific and Technical Policy." This 
Federal Law contains a different definition of innovation as the introduction of a new or a significantly improved product (service) or process, a new sales method or a new organizational method in business practice, workplace organization, or in external relations (Art. 2). Identified discrepancies may further lead to difficulties in determining the object of the experimental legal regime.

In addition, according to Article 13 of the Draft Federal Law “On the Experimental Legal Regimes of Digital Innovations," the Government of Russian Federation is authorized to decide on the creation of regulatory sandboxes in the sphere of digital innovations. At the same time, in the previous version of the Draft Law, the list of competent authorities and organizations which take part in decision-making process on the application of experimental legal regimes of regulatory sandbox was defined. These participants were as follows: 1 ) a competent governmental body, responsible for creating experimental legal regimes; 2) public companies; 3) an expert advisory body consisting of representatives of business entities and the scientific expert community; 4) business community.

This wide list of responsible entities supports the balance of public and private interests of regulators, business entities, and innovators and should be included into the provisions of the Draft Law. Meanwhile, consumer protection organizations should also be included in mention list. This measure is necessary to ensure the protection of the interests of potential consumers of the results of activities (goods, works and services) carried out under the experimental legal regime. According to experts, consumers can suffer from consequences of the application of the regime of regulatory sandbox from the testing of new products, services, or processes based on new digital technologies. ${ }^{28}$

Here we can note that in accordance with the "FinTech Regulatory Sandbox Guidelines" approved by the Monetary Authority of Singapore, the decision on the use of the regulatory sandbox is made by authorized bodies in consultation with public organizations in the interests of society as a whole, and not its individual layers. ${ }^{29}$

The duration of experimental regulation raises some doubts. In accordance with the Draft Federal Law "On the Experimental Legal Regimes of Digital Innovations," the experimental regime can be established for a period of up to 3 years. The possibility of applying the regulatory sandbox regime over such a long period of time when a business entity is in "greenhouse" conditions may adversely affect its activities or lead to the abuse of rights.

Notably, in the UAE, the validity of such a regime cannot exceed 2 years; in the UK and Australia - up to 12 months; and in Singapore - no more than 3-6 months.

28 Bromberg et al. 2017, at 332.

29 Monetary Authority of Singapore, FinTech Regulatory Sandbox Guidelines (November 2016) (Apr. 10, 2020), available at https://www.rajahtannasia.com/media/pdf/15_FinTech_RegulatorySandbox_ Guidelines.pdf. 
Moreover, legislation on regulatory sandboxes in Singapore provides for the possibility of early termination of the experimental regime if it shows negative results. It seems that a norm with similar content should be included in the Draft Federal Law "On the Experimental Legal Regimes of Digital Innovations," which will make possible to abandon hopeless projects prematurely.

The Draft Federal Law "On the Experimental Legal Regimes of Digital Innovations" does not reflect the condition of the need for prior consent of customers or counterparties to interact with the entity in respect of whose activities an experimental legal regime has been introduced. Note that this condition is contained in the legislation on regulatory sandboxes in the UK, Australia, and Singapore. Its implementation helps minimize the possible risks associated with testing digital innovations.

Finally, the list of conditions for the admissibility of experimental legal regimes in the field of digital innovations contained in the Draft Law is insufficiently detailed. In particular, conditions such as the potential utility of the object of the experimental legal regime; the reproducibility of the beneficial effect of the use of digital innovation; and the readiness of digital innovation for use require the development of special criteria and the inclusion of provisions on them in the text of the Draft Law.

\subsection{Regulatory Sandboxes in the Republic of India: The Beginning of the Legal Framework's Creation}

In view of the growing significance of digital innovations and their interface with the financial sector in Republic of India as well as financial sector entities, the Reserve Bank of India set up an inter-regulatory Working Group to look into and report on the granular aspects of FinTech, to leverage on the developments in FinTech space. ${ }^{30}$

In accordance with the Report of the Working Group of 8 February 2018, one of the key recommendations was to introduce an appropriate legal framework for a regulatory sandbox within a well-defined space and duration where the financial sector regulator will provide the requisite regulatory guidance, so as to increase efficiency, manage risks, and create new opportunities for consumers. ${ }^{31}$ Pursuant to this report, the Reserve Bank of India launched the Draft Enabling Framework for Regulatory Sandbox on 18 April 2019. . $^{32}$ The Draft Law defines the fundamental principles and objectives of the Indian model of regulatory sandbox.

30 How Regulatory Sandbox Ensures Precise Governance while Encouraging Innovations, Entrepreneur, 27 October 2017 (Apr. 10, 2020), available at https://www.entrepreneur.com/article/303762.

31 Reserve Bank of India, Report of the Working Group on FinTech and Digital Banking, 8 February 2018 (Apr. 10, 2020), available at https://rbi.org.in/scripts/PublicationReportDetails.aspx?UrIPage=\&ID=920.

32 Reserve Bank of India, Draft Enabling Framework for Regulatory Sandbox, 18 April 2019 (Apr. 10, 2020), available at https://rbi.org.in/scripts/PublicationReportDetails.aspx?UrIPage=\&ID=920. 
According to the Draft Law, a regulatory sandbox refers to live testing of new products or services in a controlled, experimental regulatory environment for which regulators may (or may not) permit certain regulatory relaxations for the limited purpose of the testing. This model allows the regulators, innovators, financial service providers (as potential deployers of the technology), and customers (as end users) to conduct field tests to collect evidence on the benefits and risks of new financial innovations while carefully monitoring and containing their risks. The Draft Law calls regulatory sandbox as "a potentially important tool which enables more dynamic, evidence-based regulatory environments which learn from, and evolve with, emerging technologies."

The objectives of the regulatory sandbox regime in India are the same as those in other countries: to provide innovative technology-led entities an environment for limited-scale testing of a new product or service that may or may not involve some relaxation in a regulatory requirement before a wider-scale launch; to implement new or emerging technology (or use of existing technology) in an innovative way to address a specific issue or bring benefits to consumers.

The Draft Law contains conditions according to which the regulatory sandbox regime can be used: a) absence of governing regulations; b) need to temporarily ease regulations for enabling the proposed innovation; $c$ ) the proposed innovation shows promise of easing or effecting delivery of financial services in a significant way.

The Draft Law also defines the target applicants for entry to the regulatory sandbox. Unlike Brazil, Australia, Russia, or Singapore, only firms in the FinTech sphere which meet the eligibility conditions prescribed for start-ups by the government can participate in the regulatory sandbox.

Participants must meet the "Fit and Proper" criteria to be included in the regulatory sandbox: a) the entity should be a start-up company incorporated and registered in India; b) the entity shall have a minimum net worth of Rs.50 lakh as per its latest audited balance sheet; $c$ ) the conduct of the bank accounts of the entity as well its promoters/directors should be satisfactory; d) satisfactory credit score of the promoter or director or entity is required; e) technological readiness of products and services for deployment in the broader market; $f$ ) the entity must demonstrate arrangements to ensure compliance with the existing regulations and laws on consumer data protection and privacy; $g$ ) adequate safeguards must be built in to IT systems to ensure that it is protected against unauthorized access, alteration, destruction, disclosure, or dissemination of records and data; robust IT infrastructure and managerial resources; $h$ ) the proposed FinTech solution should highlight an existing gap in the financial ecosystem and the proposal should demonstrate how it would address the problem, or bring benefits to consumers or the industry or perform the same work more efficiently.

The Draft Law contains the closed list of innovative products and services, which can be created under the regulatory sandbox regime: retail payments; money transfer 
services; marketplace lending; financial advisory services; wealth management services; digital identification services; smart contracts; financial inclusion products; or cyber security products. The listed products and services can only be created on the basis of: a) mobile technology applications (payments, digital identity, etc.); b) Data Analytics; c) Application Program Interface (APIs) services; d) Applications under block chain technologies; e) Artificial Intelligence and Machine Learning applications. We believe that restricted list of technologies can diminish the opportunity to use other digital innovations which already exist or will eventually appear.

At the same time, the Draft Law also contains exclusions from regulatory sandbox testing: a) cryptocurrency; b) crypto assets services; c) trading, investing, settling in crypto assets; d) Initial Coin Offerings; or e) any product/services which have been banned by the regulators of India. This list contains products and services forbidden in the territory of the Republic of India.

In contrast to the Russian regulatory sandbox model, the Indian regulatory sandbox testing regime period may last for a maximum of 12 weeks, after which a 4 week evaluation process occurs. The outcome of the testing of products, services, and technologies, as per the expected parameters including viability or acceptability under the regulatory sandbox, shall be confirmed by the Reserve Bank of India. According to the results, the regulator then decides whether the product or service is viable and acceptable under the regulatory sandbox.

The Indian Draft Law doesn't contain a list of "relaxations" for its participants. But at the same time, the legal regime of the regulatory sandbox may involve relaxations, if warranted, of some of the regulatory requirements for sandbox applicants for the duration of the regulatory sandbox on a case-to-case basis. On the one hand, such a "flexible" provision makes it possible to decide whether or not it is necessary to use relief tools, considering the specific situation. On the other hand, its uncertainty may lead to unsupervised and unfair granting of benefits.

At the end of the sandbox period, the regulatory relaxations provided to the entities will expire, and the entity must exit the regulatory sandbox. If the regulatory sandbox entity requires an extension, it should apply to the Reserve Bank of India at least one month before the expiration of the given period with valid reasons to support an application for extension; the decision of the Reserve Bank of India on the application will be final.

An important provision of the Draft Law is that sandbox testing can be discontinued any time at the discretion of the Reserve Bank of India if the entity does not achieve its intended purpose based on the latest test scenarios, expected outcomes, and or the schedule which was mutually agreed to by the sandbox entity with the Reserve Bank of India. Further, the regulatory sandbox may also be discontinued if the entity is unable to fully comply with the relevant regulatory requirements and other conditions specified at any stage during the sandbox process. The sandbox entity may also exit from the regulatory sandbox at its own discretion by informing the Reserve Bank of India one week in advance. 
The provisions of the Draft Law on consumer protection emphasizes that sandbox participants will be required to ensure that any existing obligations to the customers of the financial service under experimentation is fulfilled or addressed before exiting or discontinuing the regulatory sandbox. This means that entering the regulatory sandbox does not limit the entity's liability towards its customers, which is critical. The Draft Law stipulates customers be notified of potential risks while testing is ongoing and provided available compensation in this regard. These provisions have an important impact on maintaining not only governmental and businesses interests, but also the interests of the consumers.

\subsection{Regulatory Sandboxes in the People's Republic of China: Aspiration to Get Ahead}

Over the past few decades, China has developed into one of the world's most important research and innovation nations. Today, the People's Republic of China is the leader in technological advances among the BRICS member nations and, moreover, a global technological leader. The country's innovation drive has led to the number of private-sector companies rising fourfold in the past ten years. These firms are increasingly moving from imitation to innovation. They are also expanding out of the domestic market into the global marketplace. Today, companies like Tencent, Baidu, and Alibaba are among the top-10 Internet companies in the world. It is clear that the country has the drive and vision to become an innovation-driven economy. ${ }^{33}$

As a leader in technology advances, the People's Republic of China has succeed in creating and operating regulatory sandboxes.

China's authorities began forming the legal framework for the operation of regulatory sandboxes in 2016. Currently there are four regulatory sandboxes available in the country:

1. The Fintech Supervisory Sandbox (FSS), launched by the Hong Kong Monetary Authority (HKMA) in September 2016, allowing banks and their partnering technology firms to conduct pilot trials of their FinTech initiatives involving a limited number of participating customers without the need to achieve full compliance with the Hong Kong Monetary Authority's supervisory requirements;

2. The Securities and Futures Commission (SFC) Regulatory Sandbox set to provide a confined regulatory environment for qualified firms to conduct regulated activities utilizing financial technologies;

3. The Insurance Authority's Insurtech Sandbox (launched on 29 September 2017) to facilitate pilot runs of innovative Insurtech applications by authorized insurers to be applied in their business operations; and

4. The Regulatory Sandbox of Blockchain launched in Hangzhou Bay Industrial Campus and Dawan District Blockchain Industrial Campus of Hangzhou Bay on 19 Oc-

33 World Economic Forum, China's Innovation Ecosystem, White Paper (August 2016) (Apr. 10, 2020), available at http://www3.weforum.org/docs/WEF_GAC_On_China_Innovation_WhitePaper_2016.pdf. 
tober 2018. It was approved by the China Electronic Commerce Association (CECA) and the China Blockchain Regulatory Sandbox Commission. ${ }^{34}$

The main benefits of the Hong Kong Monetary Authority Fintech Supervisory Sandbox consist in that fact that banks operating within the HKMA sandbox are allowed to conduct pilot trials of their initiatives involving actual banking services without the need to achieve full compliance with the typical Hong Kong Monetary Authority supervisory requirements during the trial period, subject to certain parameters. Only banks authorized by the Hong Kong Monetary Authority can apply for the Fintech Supervisory Sandbox experimental regime. Both the process of applying the sandbox and the duration of the experimental legal regime of the Hong Kong Monetary Authority's Regulatory Sandbox vary and are defined on a caseby-case basis.

The Hong Kong Monetary Authority has adopted the following principles in operating the Fintech Supervisory Sandbox: (i) Boundaries. Clear definitions about the scope and phases (if any) of the pilot trial, the timing and termination arrangements; (ii) Customer protection. Measures for protecting the interests of customers during the trial, which generally cover the selection of customers who understand the associated risks and voluntarily join the trial, complaint handling, compensation of any financial losses by customers, and arrangements for customers to withdraw from the trial; (iii) Risk management control. Compensating controls for mitigating the risks arising from incomplete compliance with supervisory requirements and the risks posed to the bank's production systems and other customers; and (iv) Readiness and monitoring. Readiness of the systems and processes involved in the trial and close monitoring of the trial..$^{35}$

As previously stated, the Securities and Futures Commission's Regulatory Sandbox is set up to provide a confined regulatory environment for qualified firms to conduct regulated activities utilizing financial technologies.

Another regulatory sandbox under the Securities and Futures Commission aims to enable qualified firms, through close dialogue with and supervision by the Commission, to identify and address any risks or concerns associated with their regulated activities before their services can be provided to the wider public in Hong Kong. To minimize risk exposure to investors, the SFC may impose licensing conditions such as limiting the types of clients these firms serve or each client's maximum exposure. In addition, they are expected to have adequate investor protection measures in place. The Securities and Futures Commission's sandbox is available to firms which are fit and proper, utilize innovative technologies, and

34 China's First Regulatory Sandbox of Blockchain Launched in Hangzhou, ChainDD, 21 September 2018 (Apr. 10, 2020), available at https://english.chaindd.com/3126266.html.

35 Hong Kong Monetary Authority, Fintech Supervisory Sandbox (FSS), B1/15C, B9/29C, 6 September 2016 (Apr. 10, 2020), available at https://www.hkma.gov.hk/media/eng/doc/key-information/guidelinesand-circular/2016/20160906e1.pdf. 
are able to demonstrate a genuine and serious commitment to carry on regulated activities using FinTech. The establishment or activities of these firms should also increase the range and quality of products and services for investors and benefit the Hong Kong financial services industry.

In respect to firms operating in the Securities and Futures Commission sandbox, once a qualified firm has demonstrated that its technology is reliable and fit for purpose, and its internal control procedures have adequately addressed the risks identified, the firm may apply to the SFC for removal or variation of some or all of the licensing conditions imposed, so that it may conduct regulated activities and be subject to supervision by the Securities and Futures Commission on the same basis as licensed corporations which operate outside the sandbox. If the Securities and Futures Commission considers that a qualified firm operating in the sandbox is not fit and proper to remain licensed, its license may be revoked. Similarly, insurers may proceed to formally launch their services and products on a broader scale if they would be able comply with supervisory requirements that are applicable outside the sandbox regime. ${ }^{36}$ Firms licensed by the Hong Kong Securities and Futures Commission and start-up firms that intend to be licensed by the Securities and Futures Commission can apply for inclusion into the sandbox operated by the Securities and Futures Commission.

The principles which apply to the Securities and Futures Commission sandbox are similar to the principles of other Chinese sandboxes: a) well-defined boundaries and conditions; b) risk management controls; c) customer protection; d) resources and readiness; e) "livable" exit strategy.

The Insurance Authority launched the Insurtech Sandbox to facilitate pilot runs of innovative Insurtech applications by authorized insurers to be applied in their business operations. According to the Guidelines on the Insurance Authority Insurtech Sandbox, authorized insurers may have initiatives in applying innovative technologies in their business operations but may be uncertain if those initiatives can meet the supervisory requirements of the Insurance Authority. The Insurance Authority would consider an Insurtech initiative for a pilot run under the Sandbox to collect enough data to demonstrate to the Insurance Authority that such Insurtech application can broadly meet relevant supervisory requirements arising from its codes and guidelines and other regulatory practices.

The Insurance Authority Insurtech Sandbox has its own specific applicant requirements. According to the policy of the Insurance Authority, only authorized insurers and technology companies cooperating with them can apply for a sandbox to test Insurtech and other technology initiatives.

36 Guide to Regulatory Fintech Sandboxes Across Asia Pacific (Apr. 10, 2020), available at https://www. bakermckenzie.com/media/files/insight/publications/2018/01/qrg_ap_regulatoryfintech_jan18. pdf?la=en. 
It is very important that the Insurtech sandbox policy includes principles of the sandbox and operation within it. First, the scope of the trial must be clearly defined, including time and duration, size and type of insurance business, and targeted users, expected outcome, and success criteria of the trial.

Second, there should be adequate control procedures to achieve the objectives of the relevant supervisory requirements of the Insurance Authority.

Third, adequate safeguards should be in place to protect the interests of customers during the trial. For some cases, it may be necessary to make known to the customers that they are being placed into the pilot run which may not fully comply with the related supervisory requirements. There may be cases where appropriate arrangements should be made for customers to withdraw from the trial (e.g. refund of premiums) or to receive fair compensation for financial losses caused by failure of the trial.

Fourth, the insurer should be ready for the test in the Sandbox with adequate resources and should be able to demonstrate that the Insurtech initiative is ready for testing.

Fifth, the insurer should present an exit strategy to the Insurance Authority for the pilot run, should it need to be terminated without success. The Sandbox is not a means to bypass applicable and related supervisory requirements.

Sixth, the Insurance Authority does not intend to define parameters for the above principles nor to stipulate an exhaustive list of supervisory requirements that may potentially be relaxed within the Sandbox framework. These are subject to the nature and application of each Insurtech initiative and will be discussed on a case-by-case basis. $^{37}$

The regulations on the final aforementioned regulatory sandbox - the Regulatory Sandbox of Blockchain by the China Electronic Commerce Association (CECA) and the China Blockchain Regulatory Sandbox Commission - are still currently being developed.

\subsection{The Republic of South Africa: Looking for Proof of Regulatory Sandboxes' Legitimacy and Efficiency}

The South African Reserve Bank (SARB) is responsible for promoting an effectivelyregulated financial system within South Africa. The SARB therefore takes a balanced approach to technological innovations, considering the potential benefits and risks of each innovation. The SARB established the Financial Technology Program to strategically assess the emergence of FinTech in a structured and organized manner, and to consider its regulatory implications. The main goal of the program is to study FinTech developments and to assist policymakers in formulating frameworks in

37 Insurtech Corner, Insurance Authority (Apr. 10, 2020), available at https://www.ia.org.hk/en/aboutus/ insurtech_corner.html. 
response to these emerging innovations.$^{38}$ Another objective is to decide on the applicability of innovation facilitators. The SARB hopes to have concluded its assessment of the appropriateness of innovation facilitators by the third quarter of 2019. Clear and transparent eligibility and participation criteria will be developed to assist in the consideration of applicants into a regulatory sandbox. ${ }^{39}$

This cautious approach by South African policymakers can be explained by the criticism towards the use of experimental legal regimes (regulatory sandboxes). Critics state that global attention to money-laundering has been growing exponentially in recent years, and the concept of the regulatory sandbox has become a covert effort to get around the consumers protection laws. At the same time, correct use of the regulatory sandbox will not turn them into a method to bypass requirements. This is why smart regulation for the smart usage of the regulatory sandboxes is critical.

\section{Global World Trends in Regulatory Sandboxing: The Way to Global Regulatory Sandbox or "Sandbox for Sandboxes"}

The concept of the experimental legal regime of regulatory sandboxes has spread globally. In August 2018, the United Kingdom's Financial Conduct Authority announced the creation of the Global Regulatory Sandbox or "Global Financial Innovation Network" or "Sandbox for sandboxes." At least 12 countries would enter to the Global Regulatory Sandbox. The new alliance has agreed to experiment with financial technologies across borders. The major emerging innovation trends are increasingly global. For instance, Big Data, Artificial Intelligence, and blockchainbased solutions are being developed and deployed in different markets. ${ }^{40}$

The aims of the Global Regulatory Sandbox are enumerated in the Global Financial Innovation Network Consultation Document and include the global creation of: a) a network of regulators (information and knowledge sharing about innovation); b) joint policy work and regulatory trials (regulator collaboration such as approaches on key policy questions, exploring RegTech synergies); c) conducting cross-border innovations testing worldwide (both business to business and to consumers).

Pertinent to developing countries, Global Financial Innovation Network calls for a web of cooperation between financial regulators, assisting them with addressing common challenges and developing the capacity and knowledge of their staff. It also provides a platform for firms to interact with regulators, opportunities to

38 Caroline da Silva, South Africa Lays the Groundwork for FinTech Regulation, 2 Financial Sector Conduct Authority Bulletin 4 (2019).

39 South African Reserve Bank, FinTech release, 13 February 2018 (Apr. 10, 2020), available at https:// www.resbank.co.za/Lists/News\%20and\%20Publications/Attachments/8259/SARB\%20FinTech\%20 release $\% 2013 \% 20$ February.pdf.

40 Global Financial Innovation Network, Consultation document (August 2018) (Apr. 10, 2020), available at https://www.fca.org.uk/publication/consultation/gfin-consultation-document.pdf. 
scale ideas across borders, and reduced time to deploy products and services to the international market - an incentive which may attract more innovators into the sandbox. ${ }^{41}$

\section{Recommendations on Setting Up a Regulatory Sandbox for BRICS Countries: Keeping a Balance Between Private and Public Interests}

As previously stated, existing regulatory barriers can impede digital innovations. ${ }^{42}$ At the same time, the creation and practical application of competitive innovations are crucial for BRICS countries. But the use of technological advances must be based on the principles of the balance of both public and private interests of regulators, innovators, business entities, their counterparties, and consumers.

Analysis of the status of the legislation and legal framework of regulatory sandboxes in BRICS countries shows that the member nations apply different regulatory sandbox models. They differ in their sphere of application, the legal status of the participants of the regulatory sandboxes, tools of relaxation, and consumer and counterparty protection measures (Table 2).

Table 2: Models of the Regulatory Sandboxes in BRICS-countries (Russian Federation, Republic of India, People's Republic of China)

\begin{tabular}{|l|c|c|c|c|c|}
\hline Country & Sphere & $\begin{array}{c}\text { Applicants/ } \\
\text { Participants }\end{array}$ & Period & $\begin{array}{c}\text { Tools } \\
\text { of relaxation }\end{array}$ & $\begin{array}{c}\text { Consumers and } \\
\text { counterparties' } \\
\text { protection } \\
\text { measures }\end{array}$ \\
\hline $\begin{array}{l}\text { Russian } \\
\text { Federation }\end{array}$ & $\begin{array}{c}\text { Different } \\
\text { spheres, } \\
\text { incl. } \\
\text { FinTech }\end{array}$ & $\begin{array}{c}\text { Legal entities, sole } \\
\text { entrepreneurs, } \\
\text { governmental } \\
\text { bodies }\end{array}$ & $\begin{array}{c}3 \text { years. } \\
\text { Can be } \\
\text { prolonged }\end{array}$ & $\begin{array}{c}\text { Licensing, } \\
\text { certification, } \\
\text { accreditation, } \\
\text { etc. reliefs }\end{array}$ & $\begin{array}{c}\text { Liability } \\
\text { insurance }\end{array}$ \\
\hline $\begin{array}{l}\text { Republic } \\
\text { of India }\end{array}$ & $\begin{array}{c}\text { Different } \\
\text { spheres, } \\
\text { incl. } \\
\text { FinTech }\end{array}$ & $\begin{array}{c}\text { Authorized banks } \\
\text { and startups }\end{array}$ & $\begin{array}{c}\text { Defines on } \\
\text { case-by- } \\
\text { case basis. } \\
\text { Can be } \\
\text { prolonged }\end{array}$ & $\begin{array}{c}\text { Define on } \\
\text { case-by-case } \\
\text { basis }\end{array}$ & $\begin{array}{c}\text { Customer } \\
\text { notification; } \\
\text { compensations }\end{array}$ \\
\hline $\begin{array}{l}\text { People's } \\
\text { Republic China }\end{array}$ & $\begin{array}{c}\text { FinTech } \\
\text { (FSS); } \\
\text { FinTech } \\
\text { (SFC); } \\
\text { Insurtech } \\
\text { (IA) }\end{array}$ & $\begin{array}{c}\text { Authorized banks } \\
\text { Qualified firms and } \\
\text { startups (SFC); } \\
\text { Authorized } \\
\text { insurers (IA) }\end{array}$ & $\begin{array}{c}\text { Defined on } \\
\text { a case-by- } \\
\text { case basis. } \\
\text { Can be } \\
\text { prolonged }\end{array}$ & $\begin{array}{c}\text { Define on } \\
\text { case-by-case } \\
\text { basis }\end{array}$ & Prior consent of \\
customers
\end{tabular}

${ }^{41}$ Consultation document, supra note 40.

42 Philip Treleaven, Financial Regulation of FinTech, 3(3) Journal of Financial Perspectives 114 (2015). 
There is no doubt that the regulatory sandbox mechanism has great potential, but there are different approaches to its construction within the legislation (or legal framework) of BRICS member nations. Moreover, there are some risks connected with the application of this experimental legal regime. Therefore, regulators must work out general guidelines and recommendations on setting up the legal regime of the regulatory sandboxes among its participants.

We believe that BRICS members must develop cooperation in the sphere of setting up and operating regulatory sandboxes. It is noteworthy to mention, that all of the prerequisites for such cooperation exist in several documents: the Memorandum of Understanding on Cooperation in Science, Technology and Innovation (2015), ${ }^{43}$ the Strategy for BRICS Economic Partnership (2016), ${ }^{44}$ Digital Economic Development Initiative approved by the Business Council BRICS members in BRICS Xiamen Summit $2018,{ }^{45}$ and the Memorandum of Understanding on Joint Research in Distributed Ledger and Blockchain Technology in the Context of Developing the Digital Economy.

We propose to set up a basic principles and measures which can support the interests and rights of regulators, participants of the regulatory sandboxes, and customers. The main recommendations are as follows:

- It is necessary to clearly define "digital innovation". Also, it is necessary to detect the criteria of the admissibility of digital innovations which are to be created under the regulatory sandbox experimental legal regime;

- Determine the authorized bodies, organizations, and associations that will participate in the working group for the development of general recommendations on using regulatory sandboxes in BRICS. It is extremely important to take into account the opinion of not only regulators, but entrepreneurs and consumers also. Representatives of each of the interested sectors should be included in the working group;

- Define the scope of the regulatory sandbox regime. In this connection, the legislative initiative of Russia, in which the use of the sandbox has been moved outside the FinTech sphere, seems to be successful and promising. This should be taken over by other BRICS participants to enable them to test innovations in other areas in addition to FinTech. The expansion of the regulatory sandbox regime has become a world-wide trend - it is now used by the legislators of Singapore, China, and India;

43 Memorandum of Understanding on Cooperation in Science, Technology and Innovation between the Governments of the Federative Republic of Brazil, the Russian Federation, the Republic of India, the People's Republic of China and the Republic of South Africa (Apr. 10, 2020), available at http:// www.brics.utoronto.ca/docs/BRICS\%20STI\%20MoU\%20ENGLISH.pdf.

44 The Strategy for BRICS Economic Partnership (Apr. 10, 2020), available at http://en.brics2015.ru/ load/381830.

45 BRICS to prioritise digital economy - Survй, IOL, 4 April 2018 (Apr. 10, 2020), available at https://www. iol.co.za/business-report/economy/brics-to-prioritise-digital-economy-surve-14231613. 
- Develop clear and detailed conditions or "fit and proper criteria" for "admission" of future participants to the regulatory sandbox experimental legal regime. This, in its turn, requires the identification of the range of participants of regulatory sandboxes in BRICS. We believe that this scope cannot be limited to authorized banks (as in the People's Republic of China), but should also include startups and other business entities;

- Establish a flexible time period for the application of the experimental mode. Such terms should be set individually or on a "case-to-case" basis, following the example of Chinese regulatory sandboxes. However, a period of more than 3 years of the regulatory sandbox legal regime (as in Russia, for example) is excessive and can lead to abuse. Also, the provisions on early extension or termination from the regulatory sandbox by its participant must be established;

- Determine the system of "reliefs" for the participants of the regulatory sandbox. It is noteworthy to mention that as a general rule these include licensing, certification, accreditation, and other relaxations. But at the same time, several countries propose taxation relief, which is very controversial. This is why general approach must be developed;

- Establish provisions for the protection of potential customers and counterparties. This will likely include a wide range of measures, such as notification about the experimental legal regime, prior consent, liability insurance, and compensations. Lack of such measures or their insufficient development is the cornerstone of all regulatory sandboxes legal regimes. This is why the main criticism of these tools is insecurity of consumers and counterparties of the participants of the regulatory sandbox. We must remember that the regulatory sandbox is not a means to bypass applicable supervisory requirements. Its participants should be mindful of licensing issues and the regulatory landscape if the solution targets or has the potential to target a wider range of customers;

- Provisions on the regulatory sandboxes must also be in compliance with the legislation on protection of the competition. Application of the experimental legal regime must not allow unfair competition of its participants and their counterparties.

It is possible that unification of the rules of the regulatory sandbox experimental legal regime can lead to establishment of the Global BRICS Regulatory Sandbox in the future. This step would serve to create an opportunity for cross-border testing of the digital innovations in a safe environment for the future export and import between BRICS members and other countries.

\section{Conclusion}

The commitment of the BRICS member nations to take a leading position in the international economic and political arena requires the development of adequate legal mechanisms for the creation and application of digital innovations. As there 
is no proper legal regulation of some digital technologies in the BRICS member nations (such as artificial intelligence, for example), the implementation of regulatory sandboxes is one of the possible ways out of this situation.

At the same time, the implementation of this mechanism requires detailed and coordinated work by each of the participating countries. To apply the experimental legal regime, on the one hand, a certain flexibility of the regulator is needed to create optimal conditions for innovators. On the other hand, policymakers must design clear policy guidelines for application of such regimes in order to respect and protect the rights of potential consumers and counterparties. In this regard, the Federative Republic of Brazil, the Russian Federation, the Republic of India, the People's Republic of China, and the Republic of South Africa should jointly develop an act on the interaction and harmonization of the legislation in the field of experimental legal regimes for creating digital innovations (regulatory sandboxes).

The results shown in this research paper can be used in lawmaking in the sphere of setting up a regulatory sandbox within BRICS and among its members. Moreover, our results can be used as a foundation for further research on the experimental legal regimes for creating digital innovation technologies (regulatory sandboxes) in BRICS member nations and other countries in the world.

\section{References}

Allen H.J. Sandbox Boundaries, 22(2) Vanderbilt Journal of Entertainment \& Technology Law 299 (2019).

Arner D.W. et al. The Evolution of Fintech: A New Post-Crisis Paradigm?, 47(4) Georgetown Journal of International Law 1271 (2016). https://doi.org/10.2139/ssrn.2676553

Brigante Deorsola A. et al. Intellectual Property and Trademark Legal Framework in BRICS Countries: A Comparative Study, 49 World Patent Information 1 (2017). https:// doi.org/10.1016/j.wpi.2017.03.001

Bromberg L. et al. Fintech Sandboxes: Achieving a Balance Between Regulation and Innovation, 28(4) Journal of Banking and Finance Law and Practice 314 (2017).

Fáykiss P. et al. Regulatory Tools to Encourage FinTech Innovations: The Innovation Hub and Regulatory Sandbox in International Practice, 17(2) Financial and Economic Review 68 (2018).

Kurt S. \& Kurt U. Innovation and Labor Productivity in BRICS Countries: Panel Causality and Co-integration, 195 Procedia - Social and Behavioral Sciences 1295 (2015). https:// doi.org/10.1016/j.sbspro.2015.06.296

Nanda V.P. The "Good Governance" Concept Revisited, 603(1) The ANNALS of the American Academy of Political and Social Science 269 (2006). https://doi.org/10.1177/ 0002716205282847

Samer H. \& De Filippi P. The Expansion of Algorithmic Governance: From Code Is Law to Law Is Code, 17 Field Actions Science Reports 88 (2017). 
Stern A.D. Innovation Under Regulatory Uncertainty: Evidence from Medical Technology, 145 Journal of Public Economics 181 (2018). https://doi.org/10.1016/j.jpubeco. 2016.11.010

Treleaven Ph. Financial Regulation of FinTech, 3(3) Journal of Financial Perspectives 114 (2015).

Zetzsche D.A. et al. Regulating a Revolution: From Regulatory Sandboxes to Smart Regulation, 23(1) Journal of Corporate \& Financial Law 31 (2017). https://doi.org/10. 2139/ssrn.3018534

\section{Information about the authors}

Elizaveta Gromova (Chelyabinsk, Russia) - Associate Professor, Department of Business, Competition and Ecological Law, South Ural State University (78 Lenina Av., Chelyabinsk, 454082, Russia; e-mail: gromovaea@susu.ru).

Tjaša Ivanc (Maribor, Slovenia) - Associate Professor, Institute for Civil, Comparative and Private International Law, Faculty of Law, University of Maribor (9 Mladinska St., Maribor, 2000, Slovenia; e-mail: tjasa.ivanc@um.si). 